\section{RASPLOĐIVANJE KAMELIDA}

Autori: Dražen Đuričić i Marko Samardžija Format B5, tvrdi uvez, 114 str.

Izdavač: Veterinarski fakultet Sveučilišta u Zagrebu, Zagreb, Hrvatska, 2021. ISBN: 978-953-8006-27-2

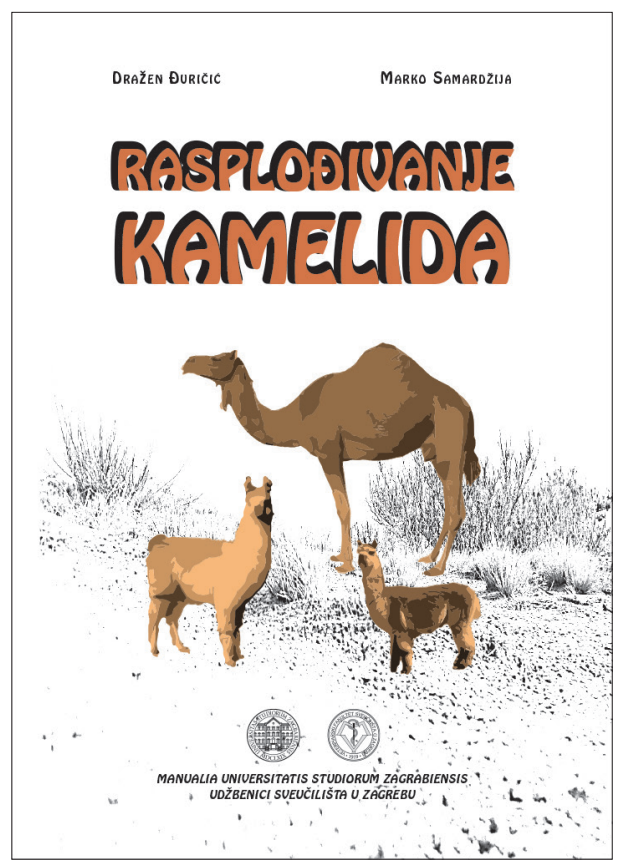

Udžbenik "Rasplođivanje kamelida“ predstavlja prvo štivo na hrvatskom jeziku koje na jednom mjestu obuhvaća činjenice vezane uz specifičnosti anatomije spolnih organa i mliječne žlijezde, fiziologije i patologije gravidnosti, porođaja, puerperija te ostale specifičnosti rasplođivanja u kamelida. U uvodnom dijelu su opisane vrste kamelida koje obitavaju u pustinjskim predjelima svijeta kao i južnoamerički kamelidi koji žive na visoravnima Anda. Slijedi detaljan opis i anatomija ženskih i muških spolnih organa te anatomija mliječne žlijezde. U poglavlju fiziologije rasplođivanja obrađene su teme spolne i rasplodne zrelosti, sezonost, neurohormonalna regulacija spolnog ciklusa i ponašanje prilikom parenja. U šestom poglavlju opisana je biotehnologija rasplođivanja (umjetno osjemjenjivanje, multipla ovulacija i embriotransfer, proizvodnja zametaka i kloniranje). Nakon toga slijede poglavlja o fizologiji i patologiji gravidnosti, porođaja i puerperija te posljednje trinaesto poglavlje o patologiji rasplođivanja koje obuhvaća prirođenu (strukturne abnormalnosti i anomalije na spolnim organima) i stečenu neplodnost. Udžbenik je izvorno djelo, a po relevantnosti za obrađenu tematiku na hrvatskom jeziku ne postoji niti jedno slično djelo. Stoga su se do sada studenti veterinarske medicine kao i svi zainteresirani za ovo nepravedno zanemerano područje uglavnom mogli služiti samo separatima stručnih i znanstvenih članaka. Želim istaknuti da ovaj udžbenik na jednom mjestu objedinjuje sve relevantne činjenice vezane uz rasplođivanje kamelida.

Udžbenik sadrži 114 stranica s približno 30-ak originalnih fotografija, slika, crteža, dijagrama, grafikona i histograma te 10-ak tabela. Obrađena materija potkrijepljena je s preko 270 navoda iz domaće i svjetske literature, pojačana iskustvom i saznanjima autora. Smatram da će ovaj udžbenik pobuditi zanimanje $u$ studenata veterinarske medicine i doktora veterinarske medicine koji svoju djelatnost obavljaju u ambulantama za velike i egzotične životinje, zoološkim vrtovima te znanstvenim ustanovama kao i srodnim strukama (agronomi i biolozi) te u svih onih koji žude za novim spoznajama o ovim predivnim, egzotičnim životinjama, no i sve prisutnijim u našoj zemlji.

Nino MAĆEŠIĆ 